\title{
Have some landscapes in the eastern Canadian boreal forest moved beyond their natural range of variability?
}

Pierre Grondin ${ }^{1 *}$, Sylvie Gauthier ${ }^{2}$, Véronique Poirier ${ }^{1}$, Patrice Tardif ${ }^{1}$, Yan Boucher $^{1}$ and Yves Bergeron ${ }^{3,4}$

\begin{abstract}
Background: In the context of ecosystem management, the present study aims to compare the natural and the present-day forested landscapes of a large territory in Quebec (Canada). Using contemporary and long-term fire cycles, each natural forest landscape is defined according to the variability of its structure and composition, and compared to the present-day landscape. This analysis was conducted to address the question of whether human activities have moved these ecosystems outside the range of natural landscape variability.
\end{abstract}

Methods: The study encompassed a forested area of $175000 \mathrm{~km} 2$ divided into 14 landscapes. Using a framework that integrates fire cycles, age structure and forest dynamics, we characterized the forest composition and age structures that resulted from three historical fire cycles (110, 140, and 180 years) representative of the boreal forest of eastern Canada. The modeled natural landscapes were compared with present-day landscapes in regard to the proportion of old-growth forests (landscape level) and the proportion of late-successional forest stands (landscape level and potential vegetation type).

Results: Four landscapes (39\%) remain within their natural range of variability. In contrast, nine landscapes (54\%) show a large gap between natural and present-day landscapes. These nine are located in the southern portion of the study area, and are mainly associated with Abies-Betula vegetation where human activities have contributed to a strong increase in the proportion of Populus tremuloides stands (early-successional stages) and a decrease of oldgrowth forest stands (more than 100 years old). A single landscape (7\%), substantially changed from its potential natural state, is a candidate for adaptive-based management.

Conclusion: Comparison of corresponding natural (reference conditions) and present-day landscapes showed that ten landscapes reflecting an important shift in forest composition and age structure could be considered beyond the range of their natural variability. The description of a landscape's natural variability at the scale of several millennia can be considered a moving benchmark that can be re-evaluated in the context of climate change. Focusing on regional landscape characteristics and long-term natural variability of vegetation and forest age structure represents a step forward in methodology for defining reference conditions and following shifts in landscape over time.

Keywords: Ecosystem management, Reference conditions, Natural variability, Resilience, Fire cycle, Age structure, Forest dynamics, Potential vegetation type, Landscape ecology, Theoretical natural landscape, Present-day landscape

\footnotetext{
* Correspondence: pierre.grondin@mffp.gouv.qc.ca

${ }^{1}$ Direction de la Recherche Forestière, Ministère des Forêts, de la Faune et

des Parcs (MFFP), 2700 rue Einstein, Québec, QC G1P 3W8, Canada

Full list of author information is available at the end of the article
} 


\section{Background}

In the context of ecosystem management, attributes such as age structure and forest composition prior to extensive human activities can be used to determine reference conditions (Stoddard et al. 2006; Boucher et al. 2011). The practice of ecosystem management demands that landscapes be managed as a whole by considering the biodiversity and ecological processes that influence forest dynamics (Keane et al. 2009). Ecosystem management and reference conditions are based on an understanding of natural variability at the landscape and stand levels (White \& Walker 1997; Kuuluvainen 2002; Gauthier et al. 2008; Cyr et al. 2009; Bergeron et al. 2017). The most important benefit of historical natural variability is increased understanding of the spectrum of conditions that frame ecosystem structure, composition, and function, when considering both temporal and spatial scales of natural disturbances and climate over the short and long term (Swanson et al. 1994; Landres et al. 1999; Keane et al. 2009). Under such conditions, ecosystems remain resilient because they have the capacity to recover after a disturbance (Holling 1973; Drever et al. 2006; Kuuluvainen 2017).

Natural ecosystems and landscapes can offer an objective benchmark for guiding short-term and long-term goals for management and restoration of ecosystems (Swetnam et al., 1999; Gauthier et al. 2008; Keane et al. 2009; Kuuluvainen 2009, 2017). Such an approach to ecosystem management increasingly considers the effect of human activities on landscape (logging, anthropogenic fires), in addition to the influence of global climate change. This view acknowledges that present-day forest conditions are different from those of the past, and new conditions and ecosystems will emerge (Boulanger et al. 2014; Kuuluvainen 2017). Under the current rates of harvesting and fire, the proportion of old forests could drop to a minimum level rarely seen in natural landscape in the past (Bouchard et al. 2015; Bergeron et al. 2017). The estimated temperature increases in our study area $\left(2{ }^{\circ} \mathrm{C}\right.$ according to RCP 4.5 and 6.0, Boulanger et al. 2014) could favor the development of ecosystems similar to those observed during the warm early Holocene period, dominated by early successional species (8500 to 6500 BP) (Ali et al. 2012). These new ecosystems could be considered alternative stable states (Scheffer \& Carpenter 2003; Jasinski \& Payette 2005), because they follow from a previous ecosystem with clearly defined characteristics. Furthermore, they are stable, because they have their own forest composition and dynamics. The initial ecosystem does not entirely disappear. Rather, it is absorbed, through the capacity of species to adapt to an ecosystem's modifications following human disturbances and climate change (Kuuluvainen \& Siitonen 2013; Gauthier et al. 2015; Kuuluvainen 2017).
The relationship between disturbance regime and forest dynamics is a key element for understanding the landscape heterogeneity of a large area, such as that considered in the present study. In natural landscapes currently characterized by a short fire cycle $(<150$ years), relatively flat topography and fairly dry climate, such as in the western portion of the Quebec boreal forest, short term natural variability is defined by an age structure with $40 \%$ to $60 \%$ of forests more than 100 years old (Boucher et al. 2011; Bergeron \& Fenton 2012). Early-successional stands dominated by Betula papyrifera, Populus tremuloides, Picea mariana and Pinus banksiana cover a large area (Gauthier et al. 1998). In these landscapes, such stands (ex. Populus tremuloides) can be perpetuated by recurrent fires (recurrent dynamics) or develop over time towards late-successional stands, generally dominated by Abies balsamea and Picea mariana (successional dynamics) (Cogbill 1985; Bergeron 2000; Lesieur et al. 2002; Couillard et al. 2012).

Natural landscapes are characterized by a toposequence composed of specific assemblages of trees and understory vegetation with similar responses to microclimate, disturbances, physical environment and soil nutrients. Each of these assemblages has specific dynamics and corresponds to a habitat type (Daubenmire 1968) or a potential vegetation type (Meidinger \& Pojar 1991; Powell 2000; Ohmann et al. 2007; Saucier et al. 2009). The determination of the proportions of the potential vegetation types and successional stages in a specific natural landscape must consider the historical variability of the fire cycle (Kuuluvainen 2009; Vijayakumar et al. 2015). Throughout the western portion of our study area, the fire cycle is estimated at 130 years during the Little Ice Age (LIA, 1550-1850) and 230 years from 1850 to 1920 (Bergeron \& Dansereau 1993; Bergeron et al. 2001).

Gradually, over the last centuries, natural landscapes of the boreal forest have been modified by human activities, and gaps between natural and present-day landscapes have widened (Foster et al. 1998; Axelsson \& Östlund 2001; Arbour \& Bergeron 2011; Kuuluvainen et al. 2015). The crucial question for the long-term sustainability of forest use is: to what extent do human activities provide suitable habitats for species populations and their dynamics (Kuuluvainen 2017)? In order to answer this question, it is essential to determine the critical thresholds of ecosystem change.

The impact of human activities makes it difficult to characterize natural landscapes, and various ways to reconstruct them have been proposed (Kuuluvainen 2002, 2017; Keane et al. 2009; Pollock et al. 2012; Laflamme et al. 2016). In this study, we used a modeling approach to quantify a theoretical natural landscape in regard to fire cycle, age structure and forest dynamics (Bergeron \& 
Dansereau 1993; Leduc et al. 1995; Gauthier et al. 1996, 1998; Harvey et al. 2002; Grondin et al. 2010). Our study focuses on a $175,000 \mathrm{~km}^{2}$ section of the Quebec boreal forest. Our goals are to a) define the natural conditions of each landscape composing this large territory in terms of age structure and forest composition of the potential vegetation types and b) to compare the natural landscape conditions and their variability to the present-day landscapes. This comparison will highlight the impact of human activities and the importance of refining our management strategies in the context of climate change.

\section{Methods}

\section{Study area}

The study area belongs to the boreal biome, specifically, to the Abies balsamea-Betula papyrifera domain in the south and the Picea mariana-feathermoss domain in the north (Saucier et al. 2009). Six of the tree species most common to this biome are well represented in both domains. These are light-demanding (Pinus banksiana Lamb., Betula papyrifera Marshall, Populus tremuloides Michaux), shade-tolerant (Abies balsamea (Linnaeus) Miller and Picea glauca (Moench) Voss), and ubiquitous species (Picea mariana (Miller) Britton, Sterns \& Poggenburgh). For the purposes of this study, the area has been subdivided into 14 landscapes (Grondin et al. 2014, Fig. 1, Table 1). All of these landscapes have experienced human activities to varying degrees for the last 100 years. The two southern extremities of the territory (west and east) have been particularly affected, and more recently, development has expanded toward the north and centre of the territory (Additional file 1: Appendix 1). In the landscapes of the southern portion, Betula papyrifera, Picea mariana and Abies balsamea are abundant and the topography is generally hilly. In the landscapes of the central portion, Betula papyrifera, Populus tremuloides, Picea mariana and Pinus banksiana are the most abundant species. Abies balsamea increases from west to east along the longitudinal gradient. In the landscapes of the northern portion, Picea mariana and Pinus banksiana are well represented. The northwestern extremity has a flat topography dominated by organic deposits and Picea mariana. The western part of the study area belongs to the Quebec Clay Belt (Veillette 1994). All these differences are the result of the combined effects of climate, natural and human disturbances, and physical environment variability (Ohmann et al. 2007; Grondin et al. 2014).

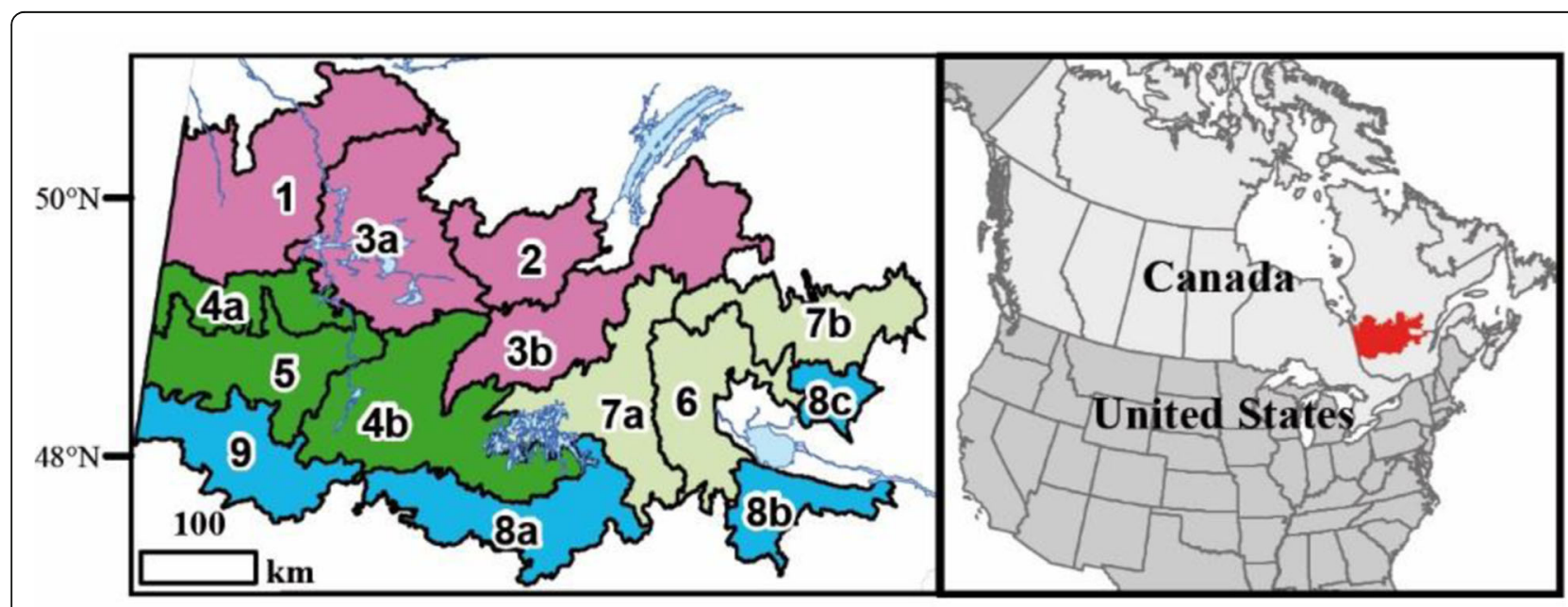

Picea mariana - feathermoss domain

Northern portion

Southern portion

Abies balsamea - Betula papyrifera domain

Northern portion

\section{Southern portion}

Fig. 1 Location of the study area (in red) and delineation of the 14 present-day landscapes considered in this study (Grondin et al. 2014). The Lac Saint-Jean region corresponds to Landscapes $6,8 \mathrm{~b}$ and $8 \mathrm{c}$ and the Abitibi region to Landscapes 5 and 9 . Réservoir Gouin is located in the western part of Landscape 7a. According to their location and attributes (vegetation, climate, disturbances, physical features), the landscapes are subdivided into two bioclimatic domains and portions of them (southern, northern). The landscapes are described in Table 1 
Table 1 Description of present-day landscapes according to the vegetation (V), climate (C), physical environment (PE), natural disturbances (ND) and human disturbances (HD). Colors represent forest classification (Fig. 1)

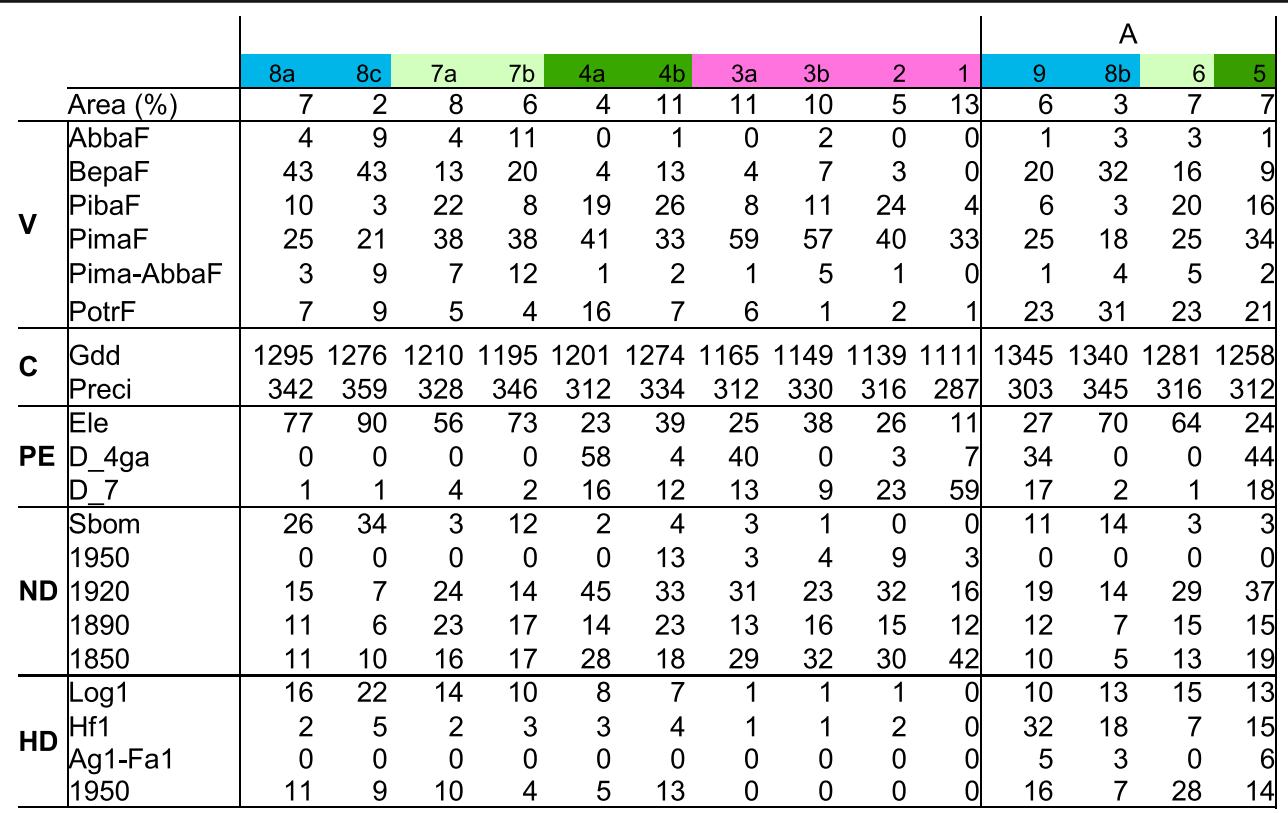

A: Landscapes of the southern part of the study affected by an increase of Populus tremuloides (PotrF). V: Vegetation: Relative area of Abies balsamea stands (AbbaF), Betula papyrifera (BepaF), Pinus banksiana (PibaF), Picea mariana (PimaF), Picea mariana and Abies balsamea (Pima-AbbaF), Populus tremuloides (PotrF) according to MFFP forest maps (1980s). C: Climate: Annual number of growing degree-days (Gdd), rainfall during the growing season (mm) (Preci) from BioSim software (1971-2000) (Régnière 1996). PE: Physical environment: Absolute difference of topographic elevation $(\mathrm{m})$ between the upper and the lower part of the hills (Ele), relative area of glaciolacustrine fine-textured deposit (clay) (D_4GA) and organic deposits (D_7) according to MFFP forest maps (1980s). ND: Natural disturbances: Relative area for light spruce budworm outbreak from MFFP forest maps (1980s) (Sbom). Relative importance of forest inventory plots classified in relation to fires: before 1870 (1850), between 1870 and 1900 (1890), 1901 and 1930 (1920) and after 1930 (1950). HD: Human disturbances: Relative area covered by logging (Log1), agriculture (Ag1), fallow farmland (Fa1) from MFFP forest maps (1970s). Frequency of human-induced fires per $100 \mathrm{~km}^{2}$ from 1938 to 1998 from MFFP archives (Hf1). Relative importance of forest inventory plots from logging since 1930 (1950)

Fires are the main natural disturbance in the study area, but scattered Abies balsamea stands have been subjected to spruce budworm outbreaks every 3040 years during the last century (Bouchard et al. 2007). The length of the fire cycle has been longer since the end of the Little Ice Age (1850) (Bergeron et al. 2014; Drobyshev et al. 2017). Fires occuring before European colonization of the area are considered natural in origin (prior to 1910 AD, Bergeron et al. 2004). Subsequently, human activities caused many fires, making it difficult to distinguish them from those of natural origin. The first period of logging activities extended mainly from 1910 to 1950 , and forest management was characterized by horse skidding and river-based log driving (Boucher et al. 2009). These activities were concentrated in the southern portion of the study area. Steam-powered trains were used on a railway that crossed this part of the territory, from the Lac Saint-Jean (east) to Abitibi (west) regions. Many fires started from embers that fell from these trains. Human fires were also abundant until close to 1950 on the agricultural lands of these regions. The second period of human activities (since 1950) was associated with mechanized logging, diesel-powered trains, lumber transport by road, and the northward expansion of logging.

\section{Modeling natural landscapes}

Natural landscapes are defined here in regard to a theoretical forest age structure and forest composition. The landscape is theoretical inasmuch as it must be reconstructed, given that natural stands are often scarce or absent due to human activities. The age structure is derived from historical fire cycles, and allows us to calculate the proportion of old forest. Forest composition is determined based on both age structure and forest modeling, and is used to define a proportion of potential vegetation types and successional stages. The proportions of old forest (more than 100 years old) and potential vegetation type-successional stages are characterized by a natural variability defined by using historical fire cycles (Appendices 2,3). This procedure excludes the effects of anthropic activities, which are considered in the analysis of the present-day landscape in a subsequent section.

\section{The boundaries of natural landscapes}

Analysis of natural landscapes is based on the same boundaries as those of present-day landscapes (Grondin et al. 2014, Fig. 1). These boundaries were defined from data collected by the Quebec Ministry of Forests, Fauna and Parks (MFFP) in the form of forest maps and forest inventory plots. Most of these data were 
elaborated during the 1970s and 1980s. The data were used to develop two matrices on which redundancy analysis was conducted (RDA), followed by Kmeans grouping (Borcard et al. 2011). For the purposes of simplification, the original codes of the present-day landscapes were modified. Although landscapes are coded from 1 to 9 , a total of 14 are included in the study because some landscapes are similar in forest composition and age structure yet are geographically distinct (e.g. 8a, 8b, 8c).

\section{Fire cycle and age structure of natural landscapes}

For each present-day landscape $(n=14)$, a natural or potential vegetation landscape was created based on historical fire cycles (Grondin et al. 2010; Additional file 1: Appendix 2). The fire cycle is defined as the time needed by natural fires to burn an area equivalent to the study area. In the eastern Canadian boreal forest, fires are generally extensive and severe (Bergeron et al. 2001). Two complementary approaches were used to estimate the fire cycle. The first and most precise is based on fire origin maps and fire cycles developed by various authors (e.g. Bergeron et al. 2001). Considering that the maps cover only $25 \%$ of the study area, a second, complementary approach relies on MFFP forest inventory plots. Each plot with no evidence of human activites $(n=$ $38,576)$ was attributed a year of origin according to the age of the oldest tree (Vijayakumar et al. 2015). This age was estimated by counting the annual rings of a core taken with a Pressler borer at the DBH of the tallest trees (three trees per plot). Some stands originated from fires older than any individual tree still standing. Considering the abundance of wood charcoals found throughout the forest soils of our study area (Frégeau et al. 2015) and the forest origin maps available (Fig. 2), we estimated that these forests originated mainly from fires that occurred in the first part of the 19th century. These forests correspond to Abies balsamea stands nowadays affected by recurrent spruce budworm outbreaks, and are scarce on mesic soils because of the short contemporary fire cycle characterizing the study area (Table 1 ). Analysis of the age of forest inventory trees at the dennial scale $(1800,1810 \ldots)$ and their distribution led to determination of fire periods centered on the years 1850 , 1890, 1920 and 1950. The 1850 period corresponds to the reported end of the Little Ice Age, while 1920 marks the beginning of intensive colonization of the region (Bergeron et al. 2001).

Each landscape is characterized by a relative proportion of trees originating from various fire periods. To define the fire cycle for each landscape, we associated an age to each fire period (ex. $1920=80$ years in 2000) and calculated a weighted mean, which corresponds to the fire cycle (Bergeron et al. 2001). Fire cycle mapping was compared to species distribution to determine whether the shortest fire cycle was associated with fire-prone species, such as Pinus banksiana (Dix \& Swan 1971). Considering the small difference in fire cycles of adjacent landscapes, we grouped these landscapes to form three main fire cycles (Additional file 1: Appendix 3). These fire cycles were subsequently used to characterize the age structure of each landscape by considering the negative exponential proposed by Van Wagner (1978) (Additional file 1: Appendix 2). For example, the fire cycle for landscape 9 is 146 years. This fire cycle is similar to that of other landscapes (e.g. 6 and 5). We classified these landscapes together in the same main fire cycle of 140 years (Additional file 1: Appendix 3b).

\section{Forest dynamics of potential vegetation types and successional stages}

To complete the description of the natural landscapes in regard to vegetation, knowledge of forest dynamics is essential (Grondin et al. 2010; Additional file 1: Appendix 2). Forest dynamics are driven by disturbances and are reflected in particular in the transition from early to late successional stages characterizing each type of potential vegetation. We defined the forest dynamics of the study area in regard to five potential vegetation types: Abies-Betula, Picea-Populus, Abies-Picea, Picea-mosses and Picea-sphagnum (Saucier et al. 2009). Each of these was sub-divided into four successional stages, defined by the relative proportion of shade tolerant forest species: early-successional (S2), juvenile (S3), intermediate (S4) and late-successional (S5) forests (Saucier et al. 1994). Stage S1 (regeneration) was not considered, since none of the forest inventory plots were non-forested.

To model forest dynamics, we characterized each MFFP forest inventory plot $(n=38,576)$ according to one of the 20 combinations of potential vegetation types-successional stages. This information was used to define the relative frequency of each combination according to 10-year age classes. We adapted a 3-parameter Weibull distribution to estimate the parameters for each relative frequency characterizing the 20 combinations. These parameters were used to model the forest dynamics. The fit of the model with the initial relative frequency was confirmed with a Kolmogorov-Smirnov statistical test showing that the Weibull distribution supports our estimation parameters. Evaluations of the Weibull distribution and Kolmogorov-Smirnov statistical test were carried out using $\mathrm{R}$ statistical language ( $\mathrm{R}$ Development Core Team 2010, library stats4). To complete the description of the 14 natural landscapes, we integrated the theoretical distribution of the age classes (landscape age structure) with the forest dynamics. 


\section{Natural range of variability of the three fire cycles characterizing the natural landscapes}

Once the fire cycles, age structure and composition of natural landscapes has been determined, the natural variability of each landscape can be estimated. This will make it possible to subsequently determine whether a landscape is inside or outside its natural range of variability.

\section{Spatial and temporal variability}

To define fire cycle length, we first drew upon reference studies that characterize fire spatial variability (Appendices 3a, 3c). For example, Le Goff et al. (2007) estimated a fire cycle of 85 years in a portion of their study area (our Landscape 2), with a variability (confidence interval) of 59 to 122 years. These three values were used to characterize the natural fire variability of Landscape 2 . We also determined a contemporary temporal variability for each fire cycle by considering first the LIA (15501850 ) and the following period, from 1850 to 1920 . To complete the description of the temporal variability, we extended this knowledge to the Holocene based on studies by Carcaillet et al. (2010) and Cyr et al. (2005).

\section{Range of variability}

After estimating the spatial and temporal variability of fire cycles for each landscape, we defined the range of variability by considering the minimal and the maximal length of the fire cycle of all the landscapes belonging to the same main fire cycle. For example, Landscape 9 is grouped with other landscapes having similar fire cycles (e.g. 7a, 6), and all the fire cycles associated with these landscapes are used to define the variability of a main fire cycle, the second (C2), which varies in length from 47 to 340 years (Additional file 1: Appendix 3a). We used these maximum and minimum lengths to estimate the absolute range of variability of each landscape in regard to forest composition (Additional file 1: Appendix 4) and age structure (proportion of forest more than 100 years old, (Additional file 1: Appendix 6).

\section{Present-day landscapes}

The present-day landscape may still be natural or it may have been essentially transformed, either by forest management activities (1950-2000) or a combination of forestry and agricultural activities (land clearing, 19101950). We evaluated landscape transformation by using the forest inventory plots and maps produced by the MFFP in the 1980's. On these maps, each forest cover stand is characterized by an age, and these were summarized in the following classes: 10 (1-20), 30-50 (21-60), $70-90(61-100)$ and $120(>100)$ years old. Using the same forest maps, we also defined each of the 14 landscapes in regard to forest composition and potential vegetation. A successional stage was attributed to each stand delimited on the forest maps. This stage relies on the forest species classification in regard to shade tolerance (Saucier et al. 1994). In characterizing the present-day landscape, recent logging was considered as a specific class that also includes agriculture and is concentrated in the Lac Saint-Jean and Abitibi regions.

\section{Comparison of natural and present-day landscapes}

To compare the age structure and forest composition (potential vegetation type and successional stage) of the 14 natural and present-day landscapes, we created five classes that express the degree of difference between the two types of landscapes. These classes range from very small $(<20 \%)$ to very large $(>80 \%)$. The formula used to calculate the gap between natural and present-day landscapes is presented in the lower section of Fig. 6 and in Additional file 1: Appendix 6. An analysis of the impact of human disturbances on forest composition in our study area underlies this analysis (Additional file 1: Appendix 1). The comparison also considers the four portions of the bioclimatic domains defined in Fig. 1 and used to describe the landscapes in Figs. 4 and 6.

\section{Results}

Fire cycles and age structure of the natural landscapes

The first fire cycle (110 years) characterizes Landscapes 2 and 4b, studied by Bergeron et al. (2001) and Le Goff et al. (2007) (Fig. 2). The natural variability associated with this fire cycle extends from 56 to 315 years (Additional file 1: Appendix 3). The minimum value characterizes the 1850-1920 period (Bergeron et al. 2001), and the maximum value, the 1550-1850 period (Le Goff et al. 2007). The rarity of Abies balsamea and the relatively high proportion of sandy deposits occupied by Pinus banksiana are related to this relatively short fire cycle (Additional file 1: Appendix 1, Table 1). Recent natural fires (1950 period) also characterize the landscapes associated with this fire cycle (Table 1).

The second fire cycle (140 years) is closely related to that obtained by fire origin maps produced by Bergeron et al. (2001), ( Fig. 2, F1 to F3) and Lesieur et al. (2002, F8). Landscapes belonging to this fire cycle have equivalent proportions (50\%) of stands originating from fires of the 1850 and 1920 periods (Table 1, Additional file 1: Appendix 3b). In accordance with contemporary ecologists (Bergeron et al. 2001, 2004; Lesieur et al. 2002) and paleoecological studies (Carcaillet et al. 2010), we estimate that the natural variability of this fire cycle extends from 47 to 340 years. The minimum value was reached during the LIA, and the maximum during an earlier period of the Holocene.

The third fire cycle (180 years) is associated to landscapes characterized by a relatively high proportion of stands of the 1850 period (Table 1, Additional file 1: 


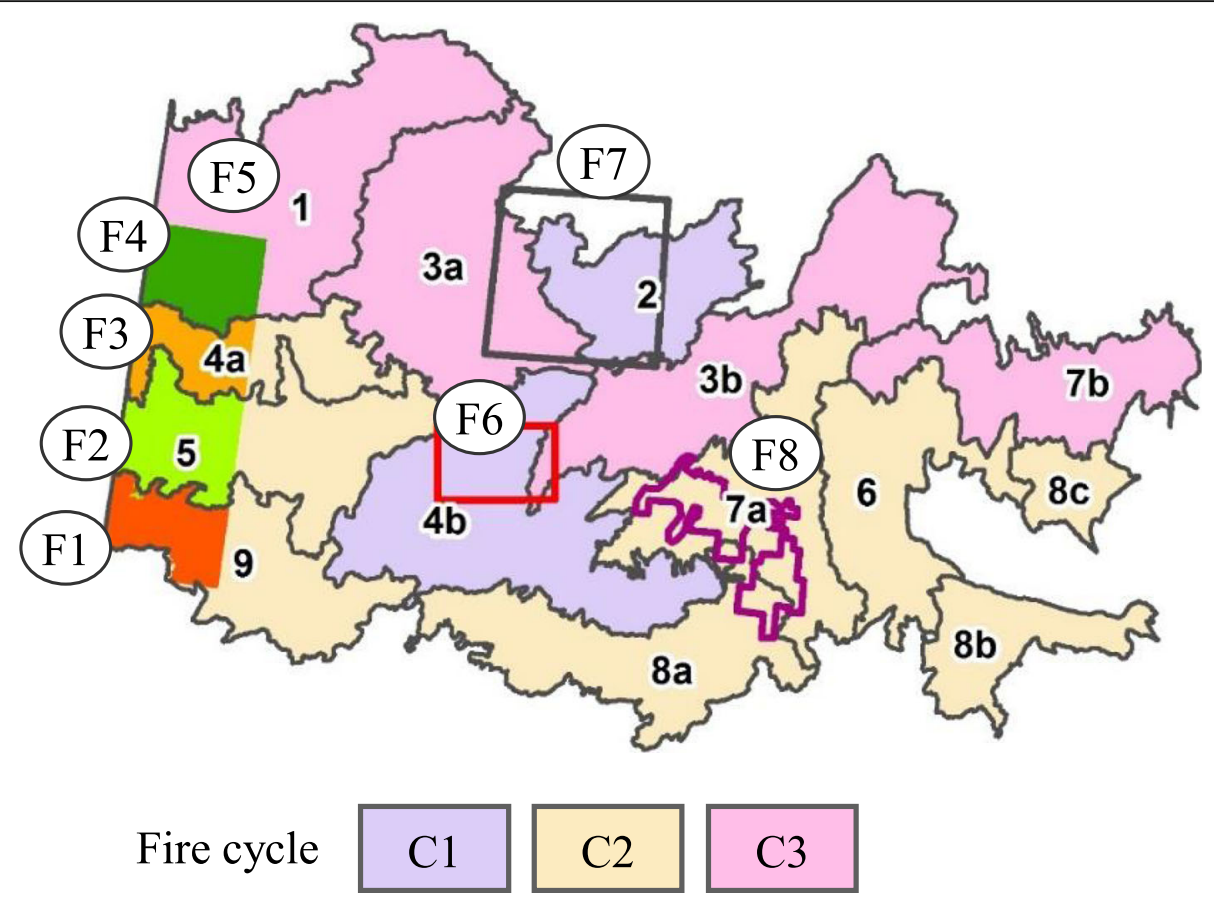

Fig. 2 Historical fire cycles (C1-110 years; C2-140 years and C3-180 years) characterizing the study area. Landscapes are delineated by dark lines. Fire origin maps (F1 to F8) used to define fire cycles are shown. F1 to F4 (colors) correspond to the sectors studied by Bergeron et al. (2001), F5 to Cyr et al. (2005), F6 to Bergeron et al. (2001), F7 to Le Goff et al. (2007) and F8 to Lesieur et al. (2002)

Appendix 3b) and the scarcity of Pinus banksiana. Four landscapes compose this third cycle. They are homogeneous, with the exception of Landscape 1 , which is distinguished by its large proportion of organic deposits and the abundance of forest stands originating from the 1850 period (Table 1). This landscape also has a long temporal fire cycle (446 years) (Cyr et al. 2005) and a relatively high proportion of forests more than 100 years old (Additional file 1: Appendix 6). However, considering the length of the historical fire cycle (146 years) reported by Bergeron et al. (2001) and the variability of the fire cycles concentrated between 100 and 190 years (Additional file 1: Appendix 3a), we classified it in the third fire cycle. The natural variability of this third fire cycle ranges from 65 to 446 years. The minimum value was reached during the LIA, and the maximum during a previous period of the Holocene (Additional file 1: Appendix 3).

\section{Forest dynamics of potential vegetation types and successional stages in the natural landscapes}

In the study area, each potential vegetation type is characterized by a particular geographical distribution and forest dynamic (Fig. 3). Potential vegetation type Abies-Betula is associated with the Abies-Betula domain; Abies-Picea is defined by colder conditions, and marks the transition between Abies and Picea domains. Picea-mosses vegetation characterizes the northern portion. Picea-sphagnum is associated with forested wetlands, mainly located in the north-western part of the study area (Landscape 1). Finally, Picea-Populus is concentrated along the Clay Belt (Landscapes 3a, 4a, 5, 9, Fig. 1).

Comparison of the forest composition and dynamics characterizing the five potential vegetation types reveals a dominance of the early-successional stage (S2) for a period of approximately 10 to $80-110$ years after the last fire. During this period, all successional stages are present in the landscape. Later, and for about 110-140 years, all successional stages remain present, but mid-successional stages (S3-S4) are well represented in the landscapes. After 140 years, stages S2, S3 and S4 gradually decrease in abundance and late-successional stands (S5) become more and more abundant.

\section{Comparison of natural and present-day landscapes}

Comparison of the natural and present-day landscapes highlights changes in forest composition and age structure under the influence of human activities. In each southern and northern portions of the two bioclimatic domains (Fig. 1), one representative landscape (8a, 6, 4b, 3a) was selected to illustrate differences between natural and present-day conditions (Figs. 4, 5 and 6).

\section{Landscapes of the southern portion of the Abies balsamea-}

\section{Betula papyrifera domain}

These landscapes $(8 \mathrm{a}, 8 \mathrm{~b}, 8 \mathrm{c}, 9)$ are naturally dominated by late stages of Abies-Betula vegetation (Fig. 4, 


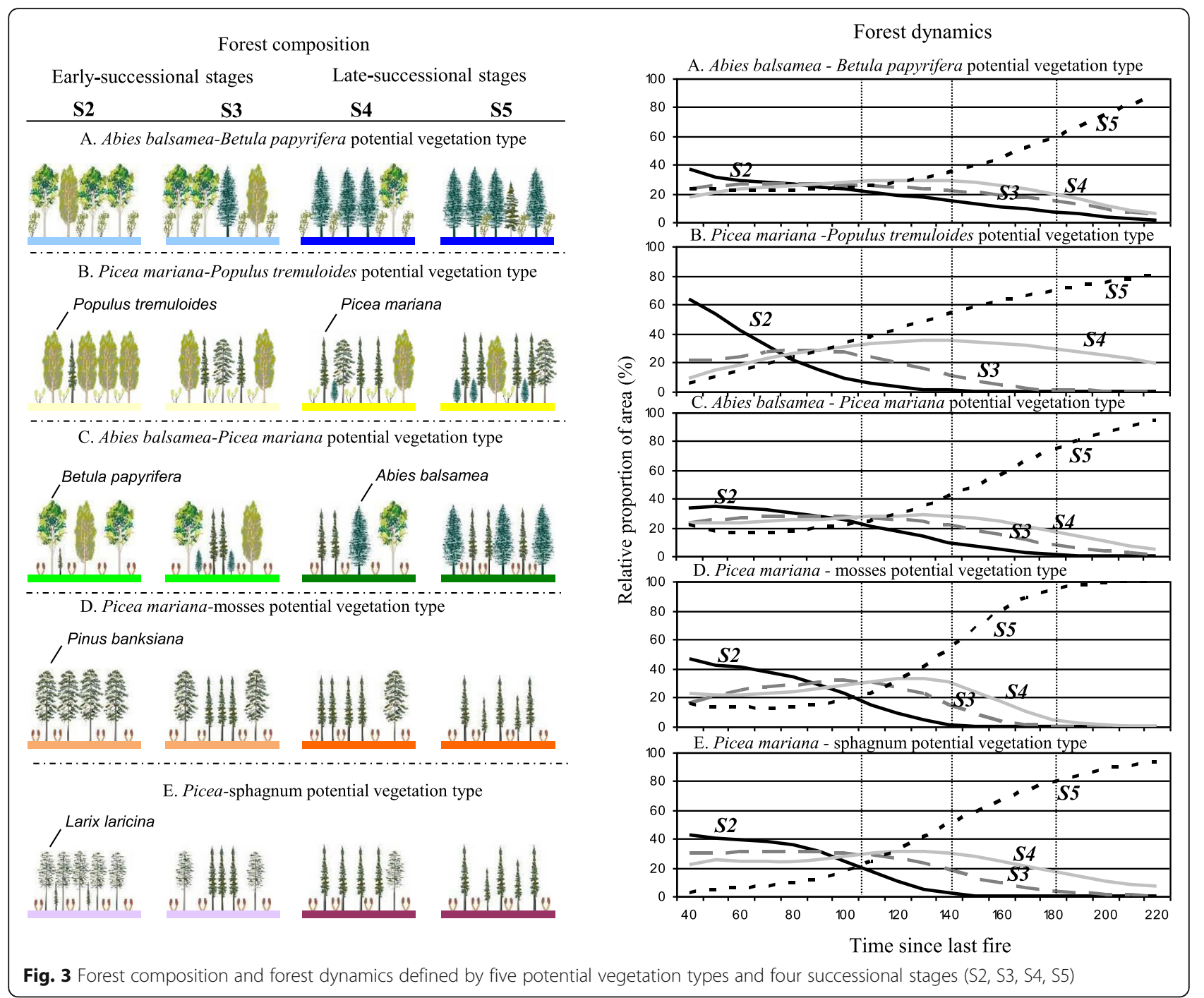

Appendices 4, 5). Comparison of the natural and present-day landscapes shows an important decrease in the proportion of late successional stages of Abies-Betula vegetation to the benefit of early successional stages. Natural landscape $8 \mathrm{a}$ is defined by a proportion of late-successional Abies-Betula vegetation making up $22 \%$ to $36 \%$ of the landscape. In the present-day landscape, this proportion is $7 \%$, which is much lower than the lowest threshold of natural variability. The increase of early successional stands, mainly Populus tremuloides, is linked to logging as well as repeated fires of human origin (Table 1, Additional file 1: Appendix 1 ). When we consider all of the potential vegetation types, the gap between the late successional stages of the natural and present-day landscapes is small. This can be explained by the limited differences between the natural and present-day landscapes of potential vegetation types other than Abies-Betula (Fig. 5a). Comparison of forest stands more than 100 years old indicates a very large gap between the natural and present-day landscapes. Natural Landscape
$8 \mathrm{a}$ is defined by a $45 \%$ proportion of forest stands more than 100 years old, which represent only $5 \%$ of the present-day landscape (Fig. 5b). This gap is very large, and similar to that in other landscapes located in this southern portion of the study area (Fig. 6).

\section{Landscapes of the northern portion of the Abies balsamea- Betula papyrifera domain}

These landscapes $(6,7 \mathrm{a}, 7 \mathrm{~b})$ are naturally dominated by late-successional stages of both Abies-Picea and Picea-mosses vegetation (Fig. 4, Appendices 4, 5). AbiesBetula vegetation is uncommon, but the gap between natural and present-day landscape is similar to that in the southern portion of the domain. The proportion of late and early successional stages of the dominant potential vegetation types decreases mainly under the influence of logging. Comparison of natural and present-day proportions of forest stands more than 100 years old indicates a very large gap for Landscape 


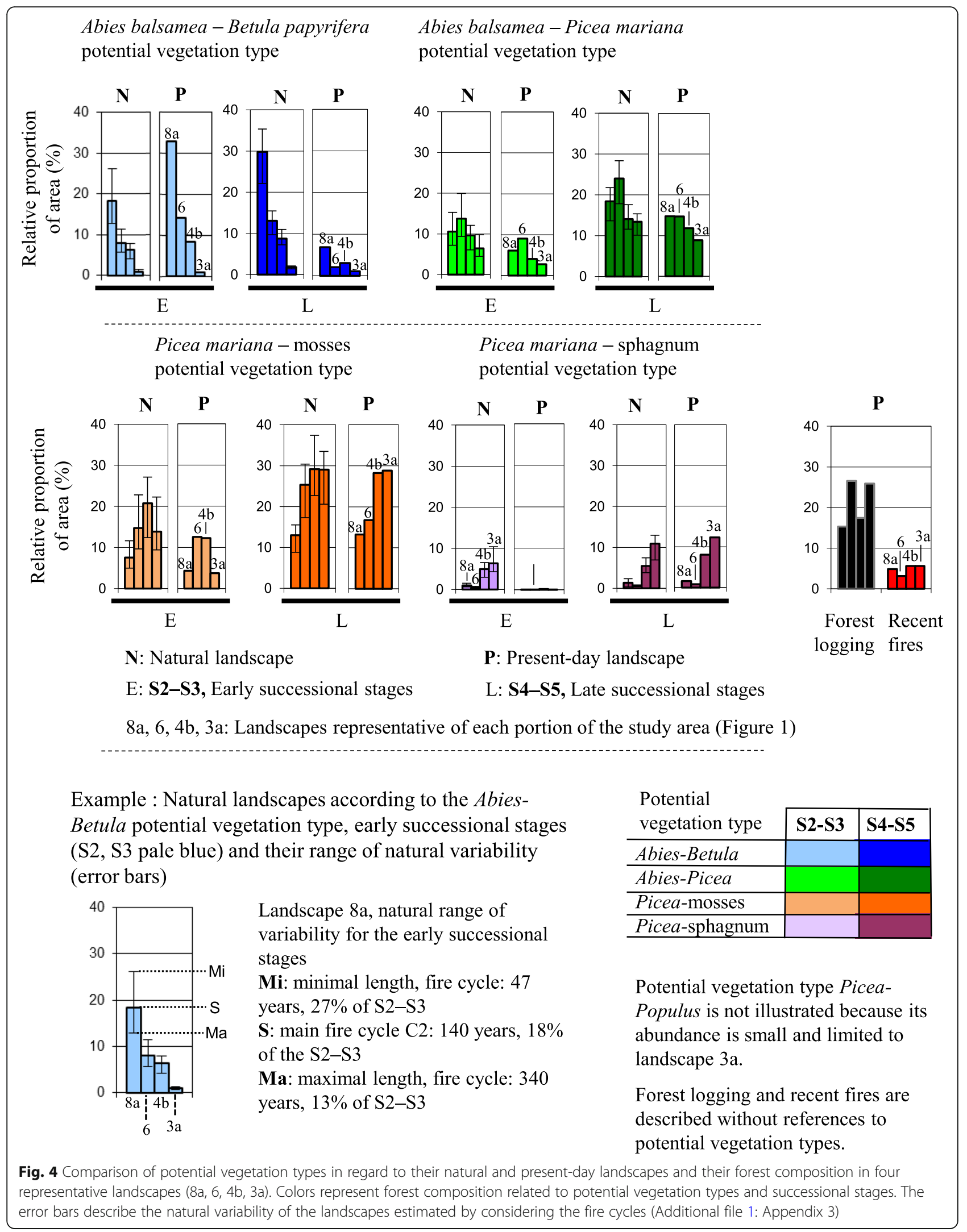




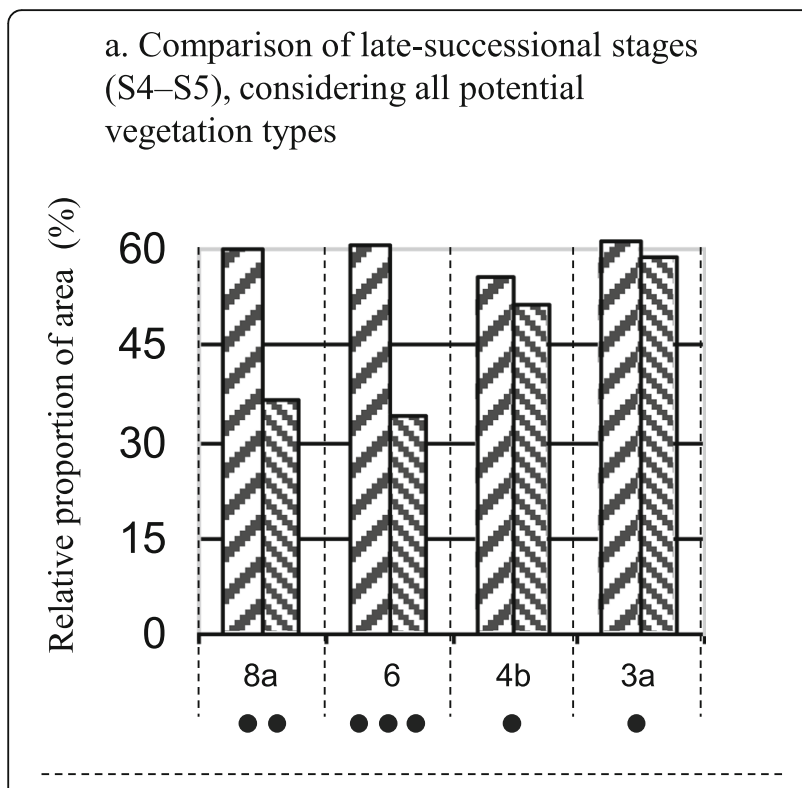

b. Comparison of forest stands more than 100 years old. The error bars describe the natural variability of the landscapes estimated by considering the fire cycles
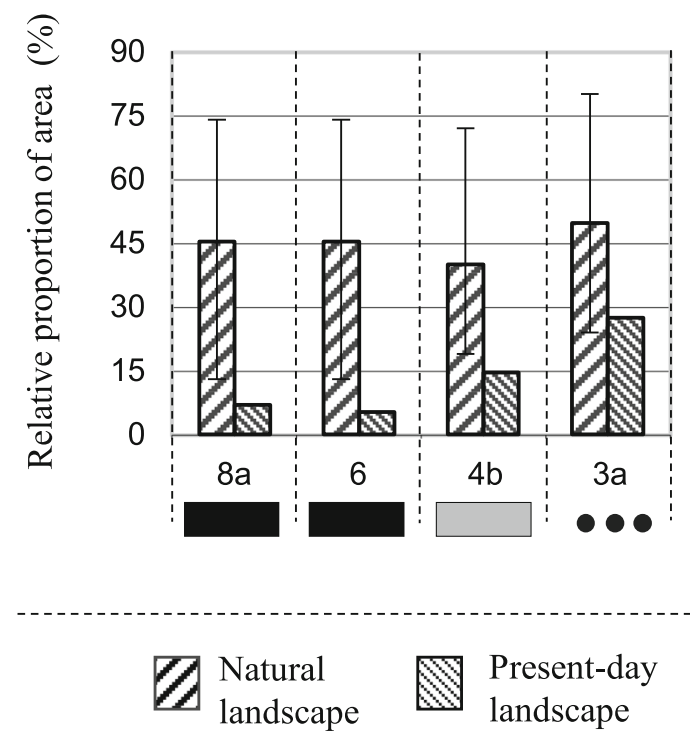

Fig. 5 Comparison of four representative landscapes (8a, 6, 4b, 3a) in regard to their natural and present-day landscapes. These landscapes are located in the four portions of the study area (Fig. 1). The gaps between the two types of landscapes (black points and rectangles) are defined in Fig. 6

6, and a large gap for Landscapes $7 \mathrm{a}$ and $7 \mathrm{~b}$ (Figs. 5 and 6). In landscape 6 , the proportion of old forest is only $5 \%$, while the minimal range of its natural variability is close to $15 \%$ (Fig. $5 \mathrm{~b}$ ). This minimal range was defined by the second fire cycle (C2), extending from 47 to 340 years.

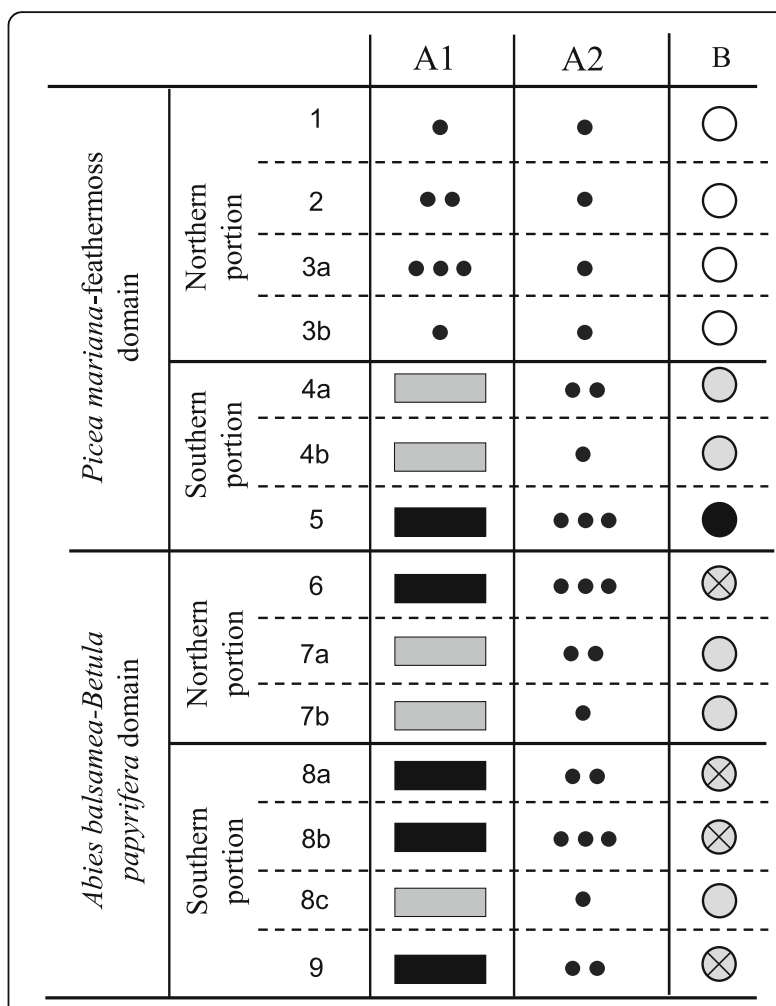

A1. Gap analysis for forest stands more than 100 years old

A2. Gap analysis for late-successional forest stands (S4-S5)

Gap between natural and present-day landscapes

(Formula: Difference between both types/highest value $\times 100$ )

$$
\begin{aligned}
& \text { Very large (more than } 80 \% \text { ) } \\
& \square \text { Large (61\%-80\%) } \\
& \text { - • Moderate (41\%-60\%) } \\
& \text { - } \quad \text { Small }(21 \%-40 \%) \\
& \text { - Very small }(\leq 20 \%)
\end{aligned}
$$

B. Classification of landscapes in regard to human activities

Landscape still inside its natural range of variability

$\bigotimes$ Landscape outside its natural range of variability but still resilient. Logging (land clearing) and human fires of the 1910-1950 period are the main causes of loss of resilience

Landscape outside its natural range of variability but still resilient. Forest logging of the 1950-2000 period is the main cause of loss of resilience

Landscape outside its natural range of variability and managed with adaptive-based strategies

Fig. 6 Summary of the comparisons between natural and presentday landscapes and classification of the landscapes in regard to human disturbances 
Landscapes of the southern portion of the Picea marianafeathermoss domain

These landscapes $(4 \mathrm{~b}, 4 \mathrm{a}, 5)$ are naturally dominated by late-successional stages of Picea-mosses vegetation, but early-successional stages of this potential vegetation type are also well represented. Potential vegetation types characterizing the Abies balsamea - Betula papyrifera domain (Abies-Betula, Abies-Picea) are present but not abundant. These landscapes have been cut more or less intensively (Additional file 1: Appendix 5), and the stands affected have mainly developed towards a forest vegetation resembling the one that preceded the disturbance (cyclic succession), with often abundant ericaceous species (Grondin \& Cimon 2003). However, although vegetation has changed little, forest maps do indicate that the gap between the proportion of old forest in natural and present-day landscapes is very large. This proportion is below the minimal range of variability for the first ( $\mathrm{C} 1$, Landscape $4 \mathrm{~b})$ and second fire cycles (C2, Landscape 4a) (Fig. 5, Additional file 1: Appendix 6).

\section{Landscapes in the northern portion of the Picea mariana- feathermoss domain}

These landscapes $(3 \mathrm{a}, 3 \mathrm{~b}, 2,1)$ are naturally dominated by late successional stages of Picea-mosses vegetation. Picea-sphagnum potential vegetation is well represented (Additional file 1: Appendix 4). The landscapes of the northern part of the study area have been affected by human activities to various degrees. On MFFP maps of the 1980s, Landscape 3a is the most affected by forest logging ( $26 \%$ of the area), which has mainly been conducted on clay deposits in recent decades. These stands will develop towards early successional Picea-Populus potential vegetation (Grondin \& Cimon 2003; Arbour \& Bergeron 2011). Landscape 2 has also been affected by recent fires (close to $10 \%$ of its area since 1970, Table 1) and early successional stages of Picea mariana-mosses vegetation, often dominated by Pinus banksiana, abound. Some of these stands are characterized by forest openings (regressive dynamics, Girard et al. 2008). At the opposite end of the spectrum, Landscape 1, dominated by organic deposits, is characterized by a high proportion of Picea mariana and sphagnum vegetation. Paludification is the main process controlling the dynamics of this landscape (Simard et al. 2007).

\section{Discussion}

The theoretical natural landscapes developed in this study and their long-term variability constitute the reference conditions for evaluating the gap between past (natural) and present-day landscapes over a large portion of the eastern Canadian boreal forest. Diverse concepts and methods were used to define the natural landscapes.
While these have some limitations, we have demonstrated to what extent human activities have affected the resilience of the landscapes described here.

\section{Pertinence of the use of potential vegetation types}

Each landscape is characterized by a toposequence of potential vegetation types. This concept constitutes the foundation of the hierarchical system of ecological classification used in Quebec (Saucier et al. 2009) and in many countries around the world (Meidinger \& Pojar 1991; Powell 2000). This vegetations allow us to conduct a comparative analysis of natural and present-day landscapes by considering entities with distinct physical features (surficial deposits, drainage, position along the slope), nutrient regime and forest dynamics (successional pathways). The present study shows the specific dynamics of the Abies-Betula potential vegetation type following human disturbances, which are characterized by abundant development of early successional species. The other potential vegetation types are less prone to changes because their nutrient regime is poorer, as revealed by the undergrowth vegetation. Abies-Betula vegetation is associated to species such as Acer spicatum (Blouin \& Berger 2002). Picea vegetations is characterized by ericaceous species and is associated with disturbances (logging and fires in boreal forest) that tend to foster invasion by this group of species (Grondin \& Cimon 2003).

The concept of potential vegetation is, however, controversial (Chiarucci et al. 2010), mainly because human activities (fire, logging) can alter vegetation to the point that the dynamics characterizing the potential vegetation type become impossible to attain. In our study area, human activities have mainly led to an increase in early successional species or the development of ericaceous species. Despite these changes in forest composition, potential vegetation types can be established. We conclude that the concept of potential vegetation type is relevant in studies comparing natural and present-day landscapes. However, the use of the potential vegetation type must be accompanied by a thorough knowledge of the impact of natural and human activities on forest dynamics.

\section{Considerations related to fire cycle, age structure and natural variability}

Our approach also involves determining the fire cycle of each of the 14 landscapes (Additional file 1: Appendix 3 ), which we synthesized into three main fire cycles. Fire origin maps and forest inventory plots $(n=38,576)$ were used to define these fire cycles. Fire origin maps provide more accurate information, but those available for the study area cover only $23 \%$ of the territory. A complete fire origin map would produce more accurate results. Considering the large surface area studied $\left(175,000 \mathrm{~km}^{2}\right)$, producing such a map was impossible. 
To establish the fire history of the total surface area studied, we relied on forest inventory plots, but these have some limitations as well. One of these is that the non-forested stands are excluded from forest plots. A forested stand is characterized by trees over $4 \mathrm{~m}$ in height covering more than $10 \%$ of the sampled area (Saucier et al. 2009). In this way, we overlooked recent fires, and the proportion of fires occurring during the 1950 period (post-1930) is underestimated, especially in the northern part of the study area (Landscape 2). For example, the proportion of area from the 1950 period in Le Goff et al. (2007) is close to $30 \%$, compared to $9 \%$ in the present study (Table 1). Because of this limitation, we have adjusted the fire cycle obtained from the forest plots to correspond to that of Le Goff et al. (2007) (Additional file 1: Appendix 3).

On the basis of fire cycles, we defined an age structure using a negative exponential distribution, with the aim of evaluating the relative proportion of area occupied by age classes ranging from 30 to 500 years. Van Wagner (1978) demonstrated that, under certain conditions, the probability distribution of stand ages in a landscape subject to periodic renewal by random fire can be expected to be exponential. However, forest age structure of the present-day landscapes cannot follow an exponential distribution due to the uneven distribution (Boychuk \& Perera 1997) and variable severity (Pennanen 2002) of disturbances (Bergeron et al. 2001; Le Goff et al. 2007). For example, in our study area, fires were concentrated mainly around 1820 and 1910-1920 (Bergeron et al. 2001, 2004). Despite the limited similitude between the present-day age structure and the theoretical one, we assume that even though the area covered by fires is irregular over time, the proportion of old forest obtained for each landscape by the negative exponential method is representative of the evolution of the landscape under natural disturbances (Gauthier et al. 1996; Cyr et al. 2009).

The natural variability of each fire cycle was determined on the basis of contemporary and Holocene studies (Additional file 1: Appendix 3). For the three main fire cycles (110, 140, 180 years), the natural variability extends from approximately 50 to 350 years. This is a very long time range, and we estimate that it reflects total contemporary and Holocene fire cycle variability. A more precise characterization of the range of natural variability of a fire cycle could be obtained by complementary analysis of existing paleoecological studies, including statistical analysis of these data (Vijayakumar et al. 2015).

\section{Considerations related to models of forest dynamics}

The forest dynamics presented in this study suggest a clear dominance of successional dynamics (Frégeau et al. 2015). Abies-Betula and Abies-Picea potential vegetation types are mainly characterized by successional forest dynamics in regions with a long fire cycle (Bergeron 2000; Lesieur et al. 2002; Lecomte \& Bergeron 2005; Couillard et al. 2012). However, in regions where the fire cycle is short ( $<150$ years), many stands repeatedly restart succession after fire, and sites occupied by late successional vegetation are rare. For example, Betula papyrifera do not develop toward Abies balsamea stands, and early successional stands define a cyclical dynamic. Mixed stands containing Picea mariana and Pinus banksiana and belonging to the Picea-mosses potential vegetation type are also generally characterized by a cyclical dynamic (Cogbill 1985; Couillard et al. 2012; Frégeau et al. 2015). These stands belong theoretically to the early successional vegetation but, according to the forest classification of successional stands in terms of shade tolerance, they are considered late successional stands (S4-S5) (Saucier et al. 1994). In this context, the classification should be adjusted.

\section{Impact of human activities on landscape changes}

During the twentieth century, human activities have resulted in an important increase in the proportion of early successional stages, and a decrease in the proportion of old-growth forests in some portions of the study area (Gauthier et al. 2008; Cyr et al. 2009). Based on the degree of impact of human activities on landscape changes, and following Kuuluvainen (2017), we have identified three levels of disturbance (Fig. 7).

\section{Landscapes still within their natural range of variability}

Four of the 14 landscapes $(1,2,3 \mathrm{a}, 3 \mathrm{~b}, 39 \%$ of the total area) are still considered within their natural range of variability (Fig. 6). These landscapes characterize the northern part of the study area. The gaps between the natural and present-day landscapes vary from very small to moderate in regard to both forest composition and age structure. These landscapes are resilient and every precaution is taken by ecosystem-based forest management approach to avoid any shift outside of their natural range of variability due to logging currently underway. Today, logging proceeds according to principles of ecosystem management, and forestry strategies are heavily regulated (Jetté et al. 2013). The main issue in this territory is the loss of timber-productive forest area caused by regeneration failure following both logging and natural fires (Girard et al. 2008). Several sites have been invaded by ericaceous shrubs, and have had to be reforested by plantations (Grondin \& Cimon 2003). Research projects are currently underway, in order to better understand processes of forest opening and rates of forest regeneration following disturbances in the context of climate change. 


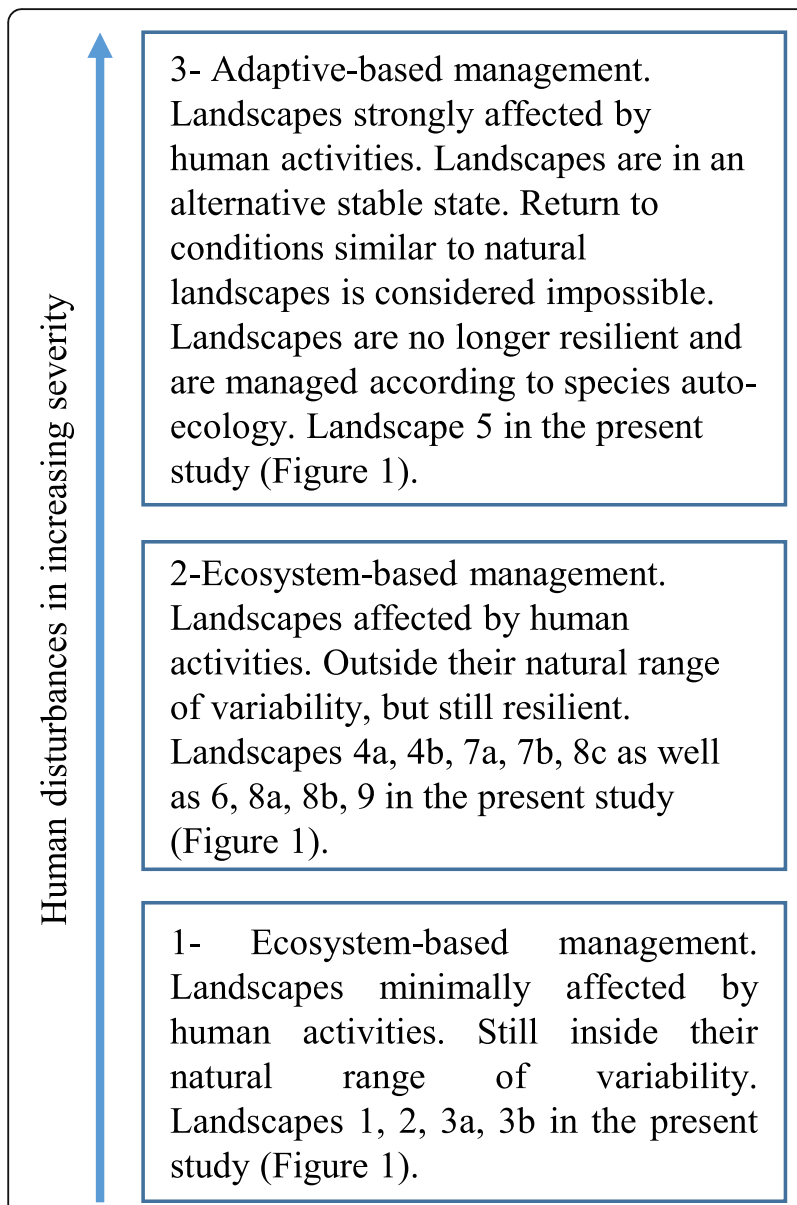

Fig. 7 Links between levels of human disturbances and the type of forest management

\section{Landscapes outside of their natural range of variability but still resilient}

On the basis of age structure and forest composition, we estimate that nine landscapes show a large gap between natural and present-day states and can be considered outside their natural range of variability (Gauthier et al. 2008; Cyr et al. 2009). These can be divided into two categories.

The first category includes four landscapes $(6,8 \mathrm{a}, 8 \mathrm{~b}$, 9, $23 \%$ of the total area), most located in the Abitibi and Lac Saint-Jean regions, the exception being Landscape $8 \mathrm{a}$, which is located in the southern portion of the study area. These landscapes have proportions of early successional stands and young forests that exceed their natural variability. Such attributes are a legacy of past human activities, including agriculture (land clearing, logging and fires) and human-induced fires caused by steam trains crossing Landscape 8A to link the Abitibi and Lac Saint-Jean regions. The influence of these two activities on landscape dynamics ceased around 1950, with the prohibition of agricultural fires and switch from steam to diesel-powered trains (Bergeron et al. 2004). Although these landscapes were known to be invaded by broadleaf species following human activities (Grondin \& Cimon 2003), they had never been evaluated to determine whether they are outside their natural variability. The expansion of Populus tremuloides, and, to a lesser extent, Betula papyrifera, is commonly observed in southern regions of Quebec that have been affected by logging and human fires during the twentieth century (Bouchard \& Domon 1997; Boucher et al. 2009; Marchais 2017).

The second category of landscapes with a large gap between their natural and present-day states includes five (4a, $4 \mathrm{~b}, 7 \mathrm{a}, 7 \mathrm{~b}, 8 \mathrm{c}, 31 \%$ of the total area) that were subjected to relatively intense logging during the 1950-2000 period. All are located on the margin of two of the province's main regions of forest development, Lac Saint-Jean and Abitibi. Logging here corresponds essentially to clearcutting, conducted without considering ecosystem management strategies first implemented in the province of Quebec in 2004 (Gauthier et al. 2008).

Landscapes classified outside of their natural variability are still resilient and are in the rehabilitation stage (Kuuluvainen 2017). These landscapes could, with appropriate silvicultural prescriptions and time, return to a composition and structure within their natural range, or be restored sufficiently to at least be able to maintain their functions (Holling 1973; Gauthier et al. 2015; Kuuluvainen 2017). Landscapes are considered resilient when they have the attributes, such as species diversity and good growth potential, to ensure a dynamic towards late-successional stands. Silvicultural strategies should notably encourage natural conifer regeneration or the planting of genetically improved coniferous varieties. Time is needed to observe the response of forest cover to silvicultural treatments. The maintenance of a certain proportion of old forest (partial cuts) is also important, due to the specific biodiversity of these habitats (Prévost et al. 2003; Cyr et al. 2009; Marchais 2017). Furthermore, the percentage of old-growth forests is expected to decrease as a result of climate change (Bergeron et al. 2017). In some cases, the target of natural variability will be achieved, but in others it will be difficult to maintain, given climate change and current harvesting levels (Gauthier et al. 2015; Bergeron et al. 2017).

\section{Landscapes outside their natural range of variability and managed with adaptive-based strategies}

Landscape 5 (Figs. 1, 7\% of total area) is considered outside its natural range of variability and has lost its resilience. Compared to landscapes discussed above (landscapes still resilient), the current forest attributes (composition and structure) of this landscape seem unlikely to restore conditions that fall within its natural range of variability. Logging and human-induced fires of 
the 20th century fostered an expansion of Populus tremuloides, which is very aggressive in clay deposits, and a significant decrease of Picea mariana. The latter species cannot regenerate after the combined action of logging and fires, due to the absence or rarity of seed banks. Abies balsamea, which have much more opportunistic reproductive strategies, are thus companions to Populus tremuloides (Grondin \& Cimon 2003; Arbour \& Bergeron 2011). Many stands are also dominated by Populus tremuloides with a dense layer of Alnus spp. The Picea-Populus natural potential vegetation type is gradually being replaced by early successional stages (S2S3) of Abies-Betula potential vegetation types. This new potential vegetation represents an alternative state, since it makes the return to a landscape resembling the original one appear impossible. This forest dynamic demonstrates that human activities can create an alternative state in the same way that natural disturbances can (Scheffer \& Carpenter 2003; Jasinski \& Payette 2005). Silvicultural strategies for Landscape 5 should thus be defined according to the principles of adaptive-based management, which focuses on the capacity of species to adapt to the changes affecting their habitat (Drever et al. 2006; Kuuluvainen et al. 2017). In Table 1, some landscapes that have the same description as Landscape 5 are considered to be outside of their natural range of variability but resilient. The specific classification of "Landscape 5" as non-resilient is closely related to the forest dynamics of Picea-Populus potential vegetation observed on flat clay deposits. Landscape 9 (south-western part of the study area) is also dominated by mesic-subhydric clay deposits, but these are mainly associated to Abies-Betula potential vegetation and an undulated relief. Landscapes 6, 8a, 8b and 9 (eastern part of the study area) are dominated by glacial deposits (till). Potential vegetation Picea-Populus is absent from these areas, and is therefore not included in their description.

We estimate that, originally, Landscape 5 had characteristics of an ecosystem belonging to the southern portion of the Picea mariana-feathermoss domain. Modifications imposed by anthropic activities in this landscape have made it resesmble an ecosystem closer to the Abies balsamea-Betula papyrifera domain today (Grondin \& Cimon 2003; Laquerre et al. 2009; Saucier et al. 2009; Arbour \& Bergeron 2011). These processes demonstrate that anthropogenic activities can provoke a change of bioclimatic domain. This hypothesis is supported by the similarity between the physical features of southern Landscape 5 and northern Landscape 4a (Fig. 1), which both lie on flat mesic-subhydric clay deposits. Landscape 5 has been greatly impacted by human activities, whereas, just to the north, Landsape 4a is in a more natural state (Additional file1: Appendix 1, Bergeron et al. 2004). Prior to human activities, which began in the early twentieth century,
Landscapes 5 and 4a were probably similar in regard to their forest composition and age structure. In Landscape 5, logging and fire have favored the development of a landscape that resembles those that are likely to be created by climate change.

\section{Conclusion}

This study aimed to define the natural conditions of the 14 landscapes composing a vast area of boreal Quebec in terms of age structure and forest composition, and considering its variability over several millenia. Our analysis showed that these natural landscapes and their variability can be considered as moving benchmarks for defining reference conditions. The study also set out to compare the 14 natural landscapes with those present today, in order to evaluate the gap between the two. Comparison revealed the unmistakable imprint left by anthropic disturbances. Our classification of the landscapes thus reflects the influence of colonization and forest logging of the Abitibi (southwest of the study area) and Lac Saint-Jean (southeast) regions since the beginning of the twentieth century. Of the 14 landscapes, nine (54\% of the total area) are outside of their natural variability and we estimate that they could return to this range of variability through appropriate silvicultural strategies.

This study is the first to present such detailed reference conditions for our study area. Boucher et al. (2011) defined reference conditions based on bioclimatic subdomains, including the western Picea mariana-feathermoss subdomain. Our results are more precise, targeting four portions of this subdomain and 14 landscapes (Fig. 1). Our study is also the first to consider the level of potential vegetation type (local scale), an important component of the classification of ecosystems in Quebec and in many countries around the world. We consider our study to be a step forward in the methodology by which reference conditions are defined, by finely respecting the regional characteristics of landscapes and characterizing each of them on the basis of the long-term natural variability of vegetation and age structure (Stoddard et al. 2006; Keane et al. 2009; Pollock et al. 2012). This variability allows us to see how reference conditions have changed along with climate and fire regime across millenia (moving benchmark) and to define critical thresholds of ecosystem change.

Our findings on natural ecosystem variability highlight the transformation of natural landscapes by human activities that occurred prior to impacts of accelerating climate change. However, the expected scale of global warming over the next decades raises important questions for ecosystem management. A return to conditions approaching those that prevailed in the past may not be possible, with the exception of 
those observed during the early Holocene period. In such a context, what management strategies will be appropriate in the future? Although climate change could amplify the effects of human and natural disturbances, boreal species have demonstrated their ability to grow in a wide range of conditions in the past, and can be expected to show important resilience. Conversely, in view of the extensive effects and the uncertainties associated with climate change, specific actions may need to be taken to maintain the health of the boreal forest (Gauthier et al. 2015). Researchers and land managers must learn to anticipate responses to future climatic conditions, and manage landscapes and ecosystems to maximize resilience of forest species (Keane et al. 2009). Regardless of what the future holds in store, studies of natural conditions and processes across several millenia are important because they form the basis of ecosystem management, and will be useful in the context of climate change.

\section{Additional file}

Additional file 1: 1- Recent consequences of human activities in the present-day landscapes. 2- Method used to define the natural landscape. 3- Natural variability of the landscapes. 4- Natural landscapes of the study area regarding the forest composition. 5-Comparison of natural and present-day landscapes on the basis of the combination of potential vegetation types and successional stages. 6-Comparison of natural and present-day landscapes on the basis of age structure and forest composition. (ZIP $7218 \mathrm{~kb}$ )

\section{Acknowledgements}

Data sources used in this study (plots, maps, archives) were collected, managed, and supervised by the staff of the MFFP since 1970. Our thanks to all of these individuals, mainly forest technicians. Stylistic revision by Karen Grislis and Germain Mercier was greatly appreciated. Our thanks to the first reviewer, Andrew Park (University of Winnipeg), to the anonymous second reviewer and to Michel Campagna (MFFP), for their insightful comments and suggestions regarding an earlier version of the manuscript. This project is part of an ongoing research project at the Direction de la recherche forestière of the MFFP (no: 142332129).

\section{Funding}

This study was funded by the Ministère des Forêts, de la Faune et des Parcs du Québec (MFFP). The funds were used mainly for the salary of the authors working for the MFFP.

\section{Availability of data and materials}

The data used in this article are quite extensive, from wide-ranging sources: 38576 forest inventory plots (1970-2000), fire maps, forest maps (1970-2000). While it is consequently impossible for us to provide access to these data directly, we will refer researchers with demonstrated relevant expertise to the appropriate data bank.

\section{Authors' contributions}

PG, SG and YBergeron designed the research. Data were analysed by PG, PT and VP. PG prepared the manuscript with imput from SG, YBergeron, PT, YBoucher and VP. All authors read and approved the final manuscript.

\section{Authors' information}

Most of the authors are forest ecologists with expertise in forest dynamics and ecosystem management. VP is a geomatician and PT a mathematician.
Ethics approval and consent to participate

Not applicable.

\section{Consent for publication}

Not applicable.

\section{Competing interests}

The authors declare that they have no competing interests.

\section{Author details}

${ }^{1}$ Direction de la Recherche Forestière, Ministère des Forêts, de la Faune et des Parcs (MFFP), 2700 rue Einstein, Québec, QC G1P 3W8, Canada. ${ }^{2}$ Ressources Naturelles Canada/Natural Resources Canada, Service Canadien des forêts/Canadian Forest Service, Centre de foresterie des Laurentides/ Laurentian Forestry Center, 1055 rue du P.E.P.S, Québec, QC G1V 4C7, Canada. ${ }^{3}$ Institut de Recherche sur les Forêts, Université du Québec en Abitibi-Témiscamingue, 445, boul. de I'Université, Rouyn-Noranda, QC J9X 5E4, Canada. ${ }^{4}$ Centre d'étude de la Forêt, Université du Québec, Montréal CP 8888 succ A, Montréal, QC H3C 3P8, Canada.

Received: 12 January 2018 Accepted: 17 July 2018

Published online: 10 August 2018

\section{References}

Ali AA, Blarquez O, Girardin MP, Hely C, Tinquaut F, El Guellab A, Valsecchi V, Terrier A, Bremond L, Genries A, Gauthier S, Bergeron Y (2012) Control of the multimillennial wildfire size in boreal North America by spring climatic conditions. Proc Natl Acad Sci U S A 109:20966-20970

Arbour ML, Bergeron Y (2011) Effect of increased Populus cover on Abies regeneration in the Picea-feathermoss boreal forest. J Veg Sci 22:1132-1142

Axelsson AL, Östlund L (2001) Retrospective gap analysis in a Swedish boreal forest landscape using historical data. For Ecol Manag 147:109-122

Bergeron Y (2000) Species and stand dynamics in the mixed woods of Québec's southern boreal forest. Ecology 81:1500-1516

Bergeron Y, Dansereau PR (1993) Predicting the composition of Canadian southern boreal forest in different fire cycles. J Veg Sci 4:827-832

Bergeron Y, Fenton N (2012) Boreal forest of eastern Canada revisited: old growth, nonfire disturbances, forest succession and biodiversity. Botany 90:509-523

Bergeron Y, Gauthier S, Flannigan M, Kafka V (2004) Fire regimes at the transition between mixedwood and coniferous boreal forest in northwestern Quebec. Ecology 85:1916-1932

Bergeron Y, Gauthier S, Kafka V, Lefort P, Lesieur D (2001) Natural fire frequency for the eastern Canadian boreal forest: consequences for sustainable forestry. Can J For Res 31:384-391

Bergeron Y, Vijayakumar DBIP, Ouzennou H, Raulier F, Leduc A, Gauthier S (2017) Projections of future forest age class structure under the influence of fire and harvesting: implications for forest management in the boreal forest of eastern Canada. Forestry 90:485-495

Blouin J, Berger JP (2002) Guide de reconnaissance des types écologiques de la région écologique $5 \mathrm{a}$ - Plaine de l'Abitibi. Ministère des Ressources naturelles du Québec, Forêt Québec, Direction des inventaires forestiers, Division de la classification écologique et productivité des stations

Borcard D, Gillet F, Legendre P (2011) Numerical ecology with R. Springer Science+Business Media, New York, USA

Bouchard A, Domon G (1997) The transformations of the natural landscapes of the haut-Saint-Laurent (Québec) and their implications on future resource management. Landsc Urban Plan 37:99-107

Bouchard M, Boucher Y, Belleau A, Boulanger Y (2015) Modélisation de la variabilité naturelle de la structure d'âge des forêts du Québec. Gouvernement du Québec, Ministère des Forêts, de la Faune et des Parcs, Direction de la recherche forestière, Québec, QC, Mém Rech For No 175. https://mffp.gouv.qc.ca/publications/forets/connaissances/recherche/ Bouchard-Mathieu/Memoire175.pdf

Bouchard M, Kneeshaw D, Messier C (2007) Forest dynamics following spruce budworm outbreaks in the northern and southern mixedwoods of Central Quebec. Can J For Res 37:763-772

Boucher Y, Arseneault D, Sirois L, Blais L (2009) Logging pattern and landscape changes over the last century at the boreal and deciduous forest transition in eastern Canada. Landsc Ecol 24:171-184

Boucher Y, Bouchard M, Grondin P, Tardif P (2011) Le registre des états de référence : intégration des connaissances sur la structure, la composition et 
la dynamique des paysages forestiers naturels du Québec méridional. Gouvernement du Québec, Ministère des Forêts, de la Faune et des Parcs, Direction de la recherche forestière, Québec, QC, Mém Rech For No. 161. https://mffp.gouv.qc.ca/publications/forets/amenagement/registre-etatsreference.pdf

Boulanger Y, Gauthier S, Burton PJ (2014) A refinement of models projecting future Canadian fire regimes using homogeneous fire regime zones. Can J For Res 44:365-376

Boychuk D, Perera AH (1997) Modeling temporal variability of boreal landscape age-classes under different fire disturbance regimes and spatial scales. Can J For Res 27:1083-1094

Carcaillet C, Richard PJH, Bergeron Y, Fréchette B, Ali AA (2010) Resilience of the boreal forest in response to Holocene fire-frequency changes assessed by pollen diversity and population dynamics. Int J Wildland Fire 19:1026-1039

Chiarucci A, Araújo MB, Decocq G, Beierkuhnlein C, Fernández-Palacios JM (2010) The concept of potential vegetation: an epitaph. J Veg Sci 4:827-832

Cogbill CV (1985) Dynamics of the boreal forests of the Laurentian highlands, Canada. Can J For Res 15:252-261

Couillard PL, Payette S, Grondin P (2012) Recent impact of fire on high-altitude balsam fir forests in south-Central Quebec. Can J For Res 42:1289-1305

Cyr D, Bergeron Y, Gauthier S, Larouche A (2005) Are the old-growth forests of the Clay Belt part of a fire-regulated mosaic? Can J For Res 35:65-73

Cyr D, Gauthier S, Bergeron Y, Carcaillet C (2009) Forest management is driving the eastern north American boreal forest outside its natural range of variability. Front Ecol Environ 7:519-524

Daubenmire R (1968) Plant communities: a textbook of plant synecology. Harper \& Row, New York, p 300

Development Core Team R (2010) R: a language and environment for statistical computing. R Foundation for Statistical Computing, Vienna http://www. Rproject.org. Accessed 19 Oct 2017

Dix RL, Swan JMA (1971) The roles of disturbance and succession in upland forest at candle Lake, Saskatchewan. Can J Bot 49:657-676

Drever CR, Peterson G, Messier C, Bergeron Y, Flannigan M (2006) Can forest management based on natural disturbances maintain ecological resilience? Can J For Res 36:2285-2299

Foster DR, Motzkin G, Slater B (1998) Land-use history as long-term broad-scale disturbance: regional forest dynamics in Central New England. Ecosystems 1: 96-119

Frégeau M, Payette S, Grondin P (2015) Fire history of the central boreal forest in eastern North America reveals stability since the mid-Holocene. The Holocene 25:1912-1922

Gauthier S, Bernier P, Kuuluvainen T, Shvidenko AZ, Schepaschenko DG (2015) Boreal forest health and global change. Science 349:819-822

Gauthier S, Leduc A, Bergeron Y (1996) Forest dynamics modelling under natural fire cycles: a tool to define natural mosaic diversity for forest management. Environ Monitor Assess 39:417-434

Gauthier S, Leduc A, Bergeron Y (1998) Un modèle pour estimer la composition et la diversité naturelles de mosaïques forestières, un exemple appliqué aux Basses-Terres d'Amos. Ressources naturelles Canada, Service canadien des forêts, Centre de foresterie des Laurentides, Sainte-Foy, Québec. Notes de recherche $n^{\circ} 4, p 4$

Gauthier S, Vaillancourt MA, Leduc A, De Grandpré L, Kneeshaw D, Morin $H_{1}$ Drapeau P, Bergeron Y (2008) Aménagement écosystémique en forêt boréale. Presses de I'Université du Québec, Québec, p 600

Girard F, Payette S, Gagnon R (2008) Rapid expansion of lichen woodlands within the closed-crown boreal forest zone over the last 50 years caused by stand disturbances in eastern Canada. J Biogeogr 35:529-537

Grondin P, Cimon A (2003) Les enjeux de biodiversité relatifs à la composition forestière. Ministère des Ressources naturelles, de la Faune et des Parcs, Québec, p 200. https://www.mffp.gouv.qc.ca/publications/ forets/connaissances/recherche/chapitre/enjeux-2003-3070.pdf. Accessed 19 Oct 2017

Grondin P, Gauthier S, Borcard D, Bergeron Y, Noël J (2014) A new approach to ecological land classification for the Canadian boreal forest that integrates disturbances. Landsc Ecol 29:1-16

Grondin P, Hotte D, Boucher Y, Tardif P, Noël J (2010) Comparaison des paysages forestiers actuels et des paysages forestiers naturels du sud de la forêt boréale du Québec à des fins d'aménagement écosystémique. Gouvernement du Québec, Ministère des Ressources naturelles, Direction de la recherche forestière, Québec, QC, Mém Rech For No 158. https://mffp.
gouv.qc.ca/publications/forets/connaissances/recherche/Grondin-Pierre/ Memoire158.pdf

Holling CS (1973) Resilience and stability of ecological systems. Annu Rev Ecol Syst 4:1-23

Jasinski JPP, Payette S (2005) The creation of alternative stable states in the southern boreal forest, Québec, Canada. Ecol Monogr 75:561-583

Jetté JP, Leblanc M, Bouchard M, Villeneuve N (2013) Intégration des enjeux écologiques dans les plans d'aménagement forestier intégré, Partie I Analyse des enjeux, Québec, gouvernement du Québec, ministère des Ressources naturelles, Direction de l'aménagement et de l'environnement forestiers 150. https://mffp.gouv.qc.ca/publications/forets/amenagement/ analyse-enjeux.pdf. Accessed 19 Oct 2017

Keane RE, Hessburg PF, Landres PB, Swanson FJ (2009) The use of historical range and variability (HRV) in landscape management. For Ecol Manag 258: 1025-1037

Kuuluvainen T (2002) Natural variability of forests as a reference for restoring and managing biological diversity in boreal Fennoscandia. Silv Fenn 36:97-125

Kuuluvainen T (2009) Forest management and biodiversity conservation on natural ecosystem dynamics in northern Europe: the complexity challenge. Ambio 38:309-315

Kuuluvainen T (2017) Restoration and ecosystem management in the boreal forest: from ecological principles to tactical solutions. In: Allison SK, Murphy SD (eds) Routledge handbook of ecological and environmental restoration. Routledge, New York, pp 93-112

Kuuluvainen T, Bergeron Y, Coates KD (2015) Restoration and ecosystem management in the circumboreal forest: background, challenges, and opportunities. In: Stanturf JA (ed) restoration of boreal and temperate forests, 2nd edn. CRC press, pp 251-270

Kuuluvainen T, Siitonen J (2013) Fennoscandian boreal forests as complex adaptative systems: properties, management, challenges and opportunies. In: Messier C, Puettmaan KJ, Coates KD (eds) Managing forests as complex adaptive systems - building resilience to the challenge of global change. Routledge, New York, pp 244-268

Laflamme J, Munson AD, Grondin P, Arseneault D (2016) Anthropogenic disturbances create a new vegetation toposequence in the Gatineau river valley, Quebec. Forests 7:17

Landres PB, Morgan P, Swanson FJ (1999) Overview of the use of natural variability concepts in managing ecological systems. Ecol Appl 9:1179-1188

Laquerre S, Leduc A, Harvey B (2009) Augmentation du couvert en peuplier fauxtremble dans les pessières noires du nord-ouest du Québec après coupe totale. Écoscience 16:483-491

Le Goff H, Flannigan MD, Bergeron Y, Girardin MP (2007) Historical fire regime shifts related to climate teleconnections in the Waswanipi area, Central Quebec, Canada. Int J Wildland Fire 16:607-618

Lecomte N, Bergeron Y (2005) Successional pathways on different surficial deposits in the coniferous boreal forest of the Quebec clay belt. Can J For Res 35:1984-1995

Leduc A, Gauthier S, Bergeron Y (1995) Prévision de la composition d'une mosaïque forestière naturelle soumise à un régime de feu : proposition d'un modèle empirique pour le nord-ouest du Québec. Dans : Méthodes et réalisations de l'écologie du paysage pour l'aménagement du territoire, édité par G. Domon et J. Falardeau, Quatrième congrès de la Société canadienne d'écologie et d'aménagement du paysage, Université Laval, Sainte-Foy, Québec, juin 1994. Polyscience Publications, Morin Heights, Québec, p 197-203

Lesieur D, Gauthier S, Bergeron Y (2002) Fire frequency and vegetation dynamics for the south-central boreal forest of Québec, Canada. Can J For Res 32: 1996-2009

Marchais M (2017) Les changements de composition dans la forêt boréale mixte de l'Ouest du Québec depuis la colonisation euro-canadienne. Thèse de maîtrise présentée à I'Université du Québec à Montréal. p 317

Meidinger D, Pojar J (1991) Ecosystems of British Columbia, British Columbia (Canada), Ministry of Forests. Special Report Series 6:330

Ohmann JL, Gregory MJ, Spies TA (2007) Influence of environment, disturbance, and ownership on forest vegetation of coastal Oregon. Ecol Appl 17:18-33

Pennanen J (2002) Forest age distribution under mixed-severity fire regimes - a simulation based analysis for middle boreal Fennoscandia. Silv Fenn 36:213-231

Pollock MM, Beechie TJ, Imaki H (2012) Using reference conditions in ecosystem restoration: an example for riparian conifer forests in the Pacific northwest. Ecosphere 3:1-23 
Powell DC (2000) Potential vegetation, disturbance, plant succession and other aspects of forest ecology. U.S. department of agriculture, forest service, Pacific northwest region. Technical publication F14-SO-TP-09-00, p 88

Prévost M, Pothier D (2003) Partial cuts in a trembling aspen conifer stand: effects on microenvironmental conditions and regeneration dynamics. Can J For Res 33:1-15

Régnière J (1996) A generalized approach to landscape-wide seasonal forecasting with temperature-driven simulations models. Environ Entomol 25:869-881

Saucier JP, Berger JP, D'Avignon H, Racine P (1994) Le point d'observation écologique : normes techniques. Ministère des Ressources naturelles du Québec, Direction de la gestion des stocks forestiers, Service des inventaires forestiers, p 116. https://mffp.gouv.qc.ca/publications/forets/connaissances/lepoint-observation-ecologique-normes-tech-34.pdf

Saucier JP, Robitaille A, Grondin P (2009) Cadre bioclimatique du Québec. In: Ordre des ingénieurs forestiers du Québec (ed) Manuel de foresterie. Éditions MultiMondes, Québec, pp 186-205

Scheffer M, Carpenter SR (2003) Catastrophic regime shifts in ecosystems: linking theory to observation. Trends Ecol Evol 18:648-656

Simard M, Lecomte N, Bergeron Y, Bernier PY, Paré D (2007) Forest productivity decline caused by successional paludification of boreal soils. Ecol Appl 17: 1619-1637

Stoddard JL, Larsen DP, Hawkins CP, Johnson RK, Norris RH (2006) Setting expectations for the ecological condition of streams: the concept of reference condition. Ecol Appl 16:1267-1276

Swanson FJ, Jones JA, Wallin DO, Cissel JH (1994) Natural variability implications for ecosystem management. In: volume II: ecosystem management: principles and applications. USDA Forest Service General Technical Report PNW-GTR 318, pp 80-94

Swetnam TW, Allen CD, Betancourt JL (1999) Applied historical ecology: using the past to manage the future. Ecol Appl 9:1189-1206

Van Wagner CE (1978) Age-class distribution and the forest fire cycle. Can J For Res 8:220-227

Veillette JJ (1994) Evolution and paleohydrology of glacial lakes Barlow and Ojibway. Quat Sci Rev 13:945-971

Vijiyakumar DBIP, Raulier F, Bernier PY, Gauthier S, Bergeron Y, Pothier D (2015) Lengthening the historical records of fire history over large areas of boreal forest in eastern Canada using empirical relationships. For Ecol Manag 347:30-39

White PS, Walker JL (1997) Approximating nature's variation: selecting and using reference information in restoration ecology. Restor Ecol 5:338-349

\section{Submit your manuscript to a SpringerOpen ${ }^{\circ}$ journal and benefit from:}

- Convenient online submission

- Rigorous peer review

- Open access: articles freely available online

- High visibility within the field

- Retaining the copyright to your article

Submit your next manuscript at $\boldsymbol{\nabla}$ springeropen.com 